\title{
Structural requirements for binding to the $\delta$ opioid receptor: Alkyl replacements at the third residue of deltorphin I
}

\author{
Deborah L. Heyl ${ }^{\mathrm{a}, *}$, Hassiba Bouzit ${ }^{\mathrm{a}}$ and Carol Mousigian ${ }^{\mathrm{b}}$ \\ ${ }^{a}$ Department of Chemistry, Eastern Michigan University, Ypsilanti, MI 48197, U.S.A. \\ ${ }^{b}$ College of Pharmacy, The University of Michigan, Ann Arbor, MI 48109, U.S.A.
}

Received 6 November 1995

Accepted 27 November 1995

Keywords: $\beta$-Substitution; Hydrophobicity; Nonpolar; Phenylalanine; Steric effect

\section{SUMMARY}

The naturally occurring heptapeptide deltorphin I (Tyr-D-Ala-Phe-Asp-Val-Val-Gly- $\mathrm{NH}_{2}$ ) exhibits extremely high affinity and selectivity for the $\delta$ opioid receptor. In an ongoing investigation of the features of this compound that confer these properties, seven new analogs of the peptide, in which phenylalanine at position three was replaced with amino acids containing alkyl side chains, were synthesized and tested for binding to $\mu, \delta$, and $\kappa$ opioid receptors. These substitutions, including tert-leucine, tert-butylalanine, $\alpha$-aminobutyric acid, norvaline, norleucine, $\beta$-cyclopentylalanine and octahydroindole-2-carboxylic acid, assessed the importance of aromaticity and lipophilicity/steric distribution of the side chain at this position in the binding interaction. Findings indicated that: (i) aromaticity at position three is not required for binding, and (ii) hydrophobic character, size, steric distribution and conformational flexibility influence affinity at the $\delta$ receptor. The data suggest that substitutions at the $\beta$-carbon of this residue disrupt the binding conformation of the peptide and possibly provide adverse steric effects.

\section{INTRODUCTION}

Deltorphins I and II (Tyr-D-Ala-Phe-Asp-ValVal-Gly- $\mathrm{NH}_{2}$ and Tyr-D-Ala-Phe-Glu-Val-ValGly- $\mathrm{NH}_{2}$, respectively), isolated from amphibian skin, possess some of the highest $\delta$ opioid affinities and selectivities among all natural and synthetic compounds known to date [1]. Studies suggest that the high selectivity of these heptapeptides is due largely to the anionic side chain of the fourth residue, and to its location relative to hydrophobic residues in the C-terminal address domain [2-4], which are essential for high $\delta$-binding affinity [5]. On the other hand, the $\mathrm{N}$-terminal message domain affects mostly signal transduction of biological responses and facilitates receptor recognition [6]. This family of $\delta$-selective peptides has been under investigation in our laboratory as well as others, in order to determine which features are instrumental in inducing high $\delta$-binding affinity and specificity. This information is essential for the specific assignment of pharmacological

*'To whom correspondence should be addressed. 
roles to each of the opioid receptor types $(\mu, \delta$, and $\kappa$ ) and their subtypes. Studying which molecular characteristics are important for the activity of these inherently selective peptides is therefore a precursor for the development of receptorspecific peptidomimetic analgesic drugs that lack unwanted side effects.

Previous studies on opioid peptides such as enkephalins have indicated that tyrosine and phenylalanine are important in the binding pharmacophore, and that $\mu$ and $\delta$ receptors might interact differently with each of these amino acid residues [7-9]. The topographical relationship of the aromatic side chains of these critical residues is important in receptor discrimination and binding. It has been demonstrated that the side chains of certain amino acids in the deltorphin sequence are amenable to modification without a substantial loss of binding affinity [3]. Evidence from structure-activity relationship (SAR) studies performed on linear and conformationally restricted opioids in our laboratory, as well as others, suggests several points, the most important of which are: (i) there are possible differences in the binding interaction at the phenylalanine residue between enkephalins and deltorphins, because the pharmacophoric residues are separated by different linear distances in the peptide chain [10-14]; (ii) electronic character and lipophilicity are important determinants in binding affinity at this residue [11-16]; and (iii) the $\mathrm{Phe}^{4}$ aromatic side chain of linear enkephalins is required for binding at the $\delta$ receptor [17], but aromaticity at the phenylalanine residue is not a requirement for $\delta$ binding in some opioid peptides, including the deltorphins [11]. In addition, conformationally constrained amino acids such as 2-aminoindane-2-carboxylic acid (Aic) and 2-aminotetralin-2-carboxylic acid (Atc) have been substituted at this position, and the peptides have maintained opioid binding characteristics $[7,15]$.

We previously reported [11] the substitution of $\mathrm{Phe}^{3}$ of deltorphin I with $\beta$-cyclohexylalanine (Cha), which resulted in a compound with high $\delta$ binding affinity. Similar $\delta$ affinity was obtained when the benzyl moiety of phenylalanine was replaced with the nonaromatic branched alkyl chain of leucine.

On the other hand, substitution of phenylalanine with valine yielded an analog with a pronounced decrease in $\delta$ affinity. Since steric bulk and lipophilicity of the side chain at residue three are two important features for high $\delta$-binding affinity [11-16], the results obtained for the valine analog were attributed to its short side chain. However, substitution of phenylalanine with isoleucine resulted in a compound with a much lower $\delta$ affinity than that of the $\mathrm{Leu}^{3}$ analog. Given the similarities of the latter three amino acid side chains, it was assumed that the presence of additional alkyl substituents at the $\beta$-carbon in valine and isoleucine might disrupt the proper conformation of the molecule or produce steric hindrance [11].

The need for further examination of these effects prompted the synthesis of seven new deltorphin analogs in which residue three was replaced by various other aliphatic amino acids with varying lipophilicity, molecular volume, and degree of substitution at the $\beta$-carbon. This study was specifically designed to further investigate the impact of a lack of aromaticity at the third residue in deltorphin $I$, as well as to assess steric influences of this residue on $\delta$ receptor binding. Although a considerable amount of SAR data have been collected on deltorphins, much remains to be learned in order to examine the role of the $\mu$ and $\delta$ receptors in the production of analgesia.

\section{METHODS}

\section{Peptide synthesis}

Most of the protected amino acids and coupling agents were purchased from Bachem California, Torrance, CA (including Tle, Abu, Nva and Nle) and Bachem Bioscience, King of Prussia, PA (including $t$-BuAla and Cpa, the latter of which was obtained in unprotected form and reacted with di-t-butyl dicarbonate in a dimethylformamide/water mixture after treatment with 2 
equiv of sodium hydroxide). Boc-octahydroindole2-carboxylic acid was purchased from Synthetech, Inc., Albany, OR. Solvents and deprotecting agents were obtained from Fisher Scientific, Itasca, IL and from Aldrich Chemical Co., Milwaukee, WI. Radioligands were purchased from New England Nuclear, Wilmington, DE, from Multiple Peptide Systems, San Diego, CA and from Amersham, Arlington Heights, IL, and frozen guinea pig brains were obtained from Rockland, Inc., Gilbertsville, PA. The peptides were prepared on a St. John's Associates (Beltsville, MD) manual shaker using standard solid phase techniques for $\mathrm{N}$ $\alpha$ - $t$-butyloxycarbonyl (Boc) protected amino acids on $p$-methylbenzhydrylamine (MBHA) resin (1.1 $\mathrm{mmol} / \mathrm{g}$ ). The side chains of tyrosine and aspartate were protected as the 2,6-dichlorocarbobenzyloxy and benzyl derivatives, respectively. The deprotection solution was $30 \%$ trifluoroacetic acid (TFA) in dichloromethane (DCM). Dicyclohexylcarbodiimide (DCC) and hydroxybenzotriazole (HOBt) were used as coupling agents. The protocol for peptide synthesis in each cycle was as follows:

(1) addition of Boc-amino acid in DCM (3 equiv);

(2) addition of HOBt ( 2.4 equiv);
(3) addition of DCC (2.4 equiv);

(4) mixing/shaking for $4 \mathrm{~h}$;

(5) washing with DCM $(3 \times 2 \mathrm{~min})$;

(6) checking for completion of reaction with the ninhydrin test [18] and recoupling if necessary;

(7) Boc deprotection with 30\% TFA in DCM (30 min);

(8) washing with DCM $(3 \times 2 \mathrm{~min})$;

(9) neutralization with diisopropylethylamine (DIEA) in DCM (10 min);

(10) washing with DCM $(3 \times 2 \mathrm{~min})$.

Simultaneous deprotection and cleavage from the resin were accomplished by treatment with $90 \%$ anhydrous $\mathrm{HF}$ and $10 \%$ anisole scavenger $(10 \mathrm{ml}$ of $\mathrm{HF}$ and $1 \mathrm{ml}$ of anisole per gram of resin) at $0{ }^{\circ} \mathrm{C}$ for $1 \mathrm{~h}$. After evaporation of the $\mathrm{HF}$, the peptide resin was washed with diethyl ether and the peptide was extracted with $70 \%$ acetonitrile $30 \%$ water (with $0.1 \%$ TFA), concentrated under reduced pressure, diluted with water, and lyophilized. Crude peptides were purified to homogeneity by preparative reversed-phase high performance liquid chromatography (RP-HPLC) on a Vydac $\mathrm{C}_{18}$ column $(2.2 \times 25.0 \mathrm{~cm}, 10 \mathrm{ml} / \mathrm{min})$ with a linear gradient of water $(0.1 \% \mathrm{TFA})$ to $50 \%$ acetonitrile $(0.1 \%$ TFA), followed by lyophilization.

TABLE I

OPIOID RECEPTOR BINDING AFFINITIES OF DELTORPHIN ANALOGS

\begin{tabular}{|c|c|c|c|c|}
\hline \multirow[t]{2}{*}{ Peptide } & \multirow[t]{2}{*}{ Compound no. } & \multicolumn{2}{|c|}{ Binding $\mathrm{K}_{\mathrm{i}}(\mathrm{nM})^{\mathrm{a}}$} & \multirow[t]{2}{*}{$\mathrm{K}_{\mathrm{i}}(\mu) / \mathrm{K}_{\mathrm{i}}(\delta)$} \\
\hline & & DAMGO & DPDPE & \\
\hline Y-a-F-D-V-V-G-NH ${ }_{2}$ & deltorphin I & $677 \pm 66.0$ & $1.73 \pm 0.211$ & 391 \\
\hline Y-a-(Tle)-D-V-V-G-NH ${ }_{2}$ & 1 & $>10000^{\mathrm{b}}$ & $2590 \pm 207$ & - \\
\hline $\mathrm{Y}-\mathrm{a}-(t-\mathrm{BuAla})-\mathrm{D}-\mathrm{V}-\mathrm{V}-\mathrm{G}-\mathrm{NH}_{2}$ & 2 & $3040 \pm 480$ & $56.6 \pm 8.50$ & 53.7 \\
\hline $\mathrm{Y}-\mathrm{a}-(\mathrm{Abu})-\mathrm{D}-\mathrm{V}-\mathrm{V}-\mathrm{G}-\mathrm{NH}_{2}$ & 3 & $>10000^{\circ}$ & $79.1 \pm 13.8$ & - \\
\hline $\mathrm{Y}-\mathrm{a}-(\mathrm{Nva})-\mathrm{D}-\mathrm{V}-\mathrm{V}-\mathrm{G}-\mathrm{NH}_{2}$ & 4 & $2570 \pm 189$ & $27.5 \pm 3.97$ & 93.5 \\
\hline $\mathrm{Y}-\mathrm{a}-(\mathrm{Nle})-\mathrm{D}-\mathrm{V}-\mathrm{V}-\mathrm{G}-\mathrm{NH}_{2}$ & 5 & $1020 \pm 96.1$ & $10.2 \pm 0.712$ & 100 \\
\hline $\mathrm{Y}-\mathrm{a}-(\mathrm{Cpa})-\mathrm{D}-\mathrm{V}-\mathrm{V}-\mathrm{G}-\mathrm{NH}_{2}$ & 6 & $4260 \pm 293$ & $366 \pm 30.4$ & 11.6 \\
\hline $\mathrm{Y}-\mathrm{a}-(\mathrm{Oic})-\mathrm{D}-\mathrm{V}-\mathrm{V}-\mathrm{G}-\mathrm{NH}_{2}$ & 7 & $>10000^{\mathrm{d}}$ & $423 \pm 21.9$ & - \\
\hline
\end{tabular}

DAMGO $=\left[{ }^{3} \mathrm{H}\right]\left[\mathrm{D}-\mathrm{Ala}^{2}, \mathrm{NMePhe}{ }^{4}, \mathrm{Gly}{ }^{5}\right.$-ol $]$ enkephalin; DPDPE $=\left[{ }^{3} \mathrm{H}\right]\left[\mathrm{D}-\mathrm{Pen}^{2}, \mathrm{D}-\mathrm{Pen}^{5}\right]$ enkephalin.

a Average values were determined from two to four assays performed in triplicate, \pm standard error of the mean; two assays were performed to determine $\mu$ and $\kappa$ affinity constants in excess of $10 \mu \mathrm{M}$. Displacement against the $\kappa$ ligand U69,593 was found to be less than $7.0 \%$ at $10 \mu \mathrm{M}$ for all analogs.

b $32.0 \%$ displacement at $10 \mu \mathrm{M}$.

c $23.7 \%$ displacement at $10 \mu \mathrm{M}$.

d $26.0 \%$ displacement at $10 \mu \mathrm{M}$. 
<smiles>CC(C)(C)C(N)C(=O)O</smiles>

Tle (1)

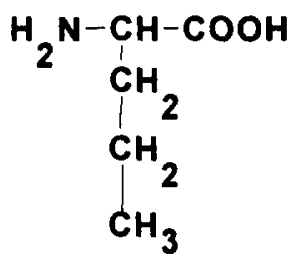

Nva (4)<smiles>CC(C)(C)CC(N)C(=O)O</smiles>

tBuAla (2)<smiles>CCCCC(N)C(=O)O</smiles>

Nle (5)<smiles>CCC(N)C(=O)O</smiles>

Abu (3)

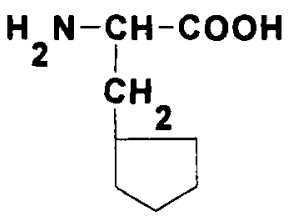

Cpa (6)<smiles>O=C(O)C1CC2CCCCC2N1</smiles>

Oic (7)

Fig. 1. Structures of the amino acids in the third position of compounds $1-7$.

\section{Peptide analysis}

Peptide purity was assessed by analytical RPHPLC. Peaks were monitored at 230 and $280 \mathrm{~nm}$. All compounds were at least $95 \%$ pure as analyzed by peak integration. Proton nuclear magnetic resonance ('H NMR) spectra were obtained on a Bruker spectrometer at $250 \mathrm{MHz}$. Samples (approx. $1 \mathrm{mg}$ ) were dissolved in DMSO. Diagnostic resonances and peak patterns confirmed the presence of all indicated residues. Electrospray mass spectrometry confirmed the appropriate molecular weights.

\section{Opioid receptor binding assays}

Receptor binding assays measured displacement by the test compounds of radiolabelled receptorselective ligands from guinea pig brain homo- genates, using $\left.1.2 \mathrm{nM}{ }^{3} \mathrm{H}\right] \mathrm{DAMGO}$ for the $\mu$ receptor, $2.5 \mathrm{nM}\left[{ }^{3} \mathrm{H}\right] \mathrm{DPDPE}$ for the $\delta$ receptor and $1.0 \mathrm{nM}\left[{ }^{3} \mathrm{H}\right] \mathrm{U} 69,593$ for the $\mathrm{K}$ receptor. This protocol has been described previously [13]. $\mathrm{IC}_{50}$ values were obtained by linear regression from plots relating inhibition of specific binding to the logarithm of 12 different ligand concentrations, using the RADLIG computer software (Biosoft Software, Cambridge, UK) [19]. For binding to $\mathrm{K}$ receptors, which was expected to be weak, the protocol was altered to include only five ligand concentrations and was performed in duplicate. $\mathrm{K}_{\mathrm{i}}$ values were calculated using values for $\mathrm{K}_{\mathrm{D}}$ of each ligand. Saturation binding experiments determined the $\mathrm{K}_{\mathrm{D}}$ range of each ligand as follows: $\left[{ }^{3} \mathrm{H}\right]$ DAMGO $=1.31-3.60 \mathrm{nM} ;\left[{ }^{3} \mathrm{H}\right] \mathrm{DPDPE}=$ $1.60-1.72 \mathrm{nM}$; and $\left.{ }^{3} \mathrm{H}\right] \mathrm{U} 69,593=1.13-1.40 \mathrm{nM}$. 
$\mathrm{K}_{\mathrm{i}}$ values reported represent the mean of two to four determinations, each performed in triplicate.

\section{RESULTS}

All newly synthesized deltorphin analogs were assayed for binding affinity to opioid receptors. The amino acids substituted at position three are depicted in Fig. 1, and Table 1 summarizes the binding affinity data obtained. For comparison, Table 1 also lists the opioid binding affinities of deltorphin I. Binding to $\kappa$ receptors was negligible for all compounds. While binding affinities for $\mu$ receptors were assessed, none of the analogs displayed significant affinity for this receptor (including the lead compound, deltorphin I). Therefore, no consistent observation can be made about the binding pocket of the $\mu$ receptor, and the following discussion will focus on effects at the $\delta$ receptor. Physicochemical data for all newly reported analogs are provided in Table 2. The relative RP-HPLC elution times of the analogs provide a good measure of their relative lipophilicities, commensurate with other utilized scales of hydrophobicity [20].

For the peptide containing tert-leucine (Tle), analog $1, \delta$ binding was effectively reduced 1500 fold $\left(\mathrm{K}_{\mathrm{i}}=2590 \mathrm{nM}\right)$. In fact, this modification proved to be the poorest for $\delta$-receptor binding of all those reported here. In compound 2 , substitution of phenylalanine with tert-butylalanine $(t-$ $\mathrm{BuAla})$ resulted in a markedly stronger binding affinity $\left(\mathrm{K}_{\mathrm{i}}=56.6 \mathrm{nM}\right)$ than that of the Tle ana$\log$, though it was still reduced relative to that of deltorphin $\mathrm{I}$.

In the next group of analogs (3-5), nonbranched alkyl side chains of varying length replaced the benzyl moiety of the native $\mathrm{Phe}^{3}$. Analog 3 consisted of a substitution with $\alpha$-aminobutyric acid (Abu), which gave rise to a reduction in $\delta$-binding affinity $\left(\mathrm{K}_{\mathrm{i}}=79.1 \mathrm{nM}\right)$. This was not unanticipated, given the small ethyl side chain of Abu. However, this compound retained good $\delta$ selectivity, largely due to a drastic reduction in $\mu$ receptor affinity. Norvaline (Nva) proved to be an adequate substitution for phenylalanine in analog 4; the $\delta$-binding affinity $\left(\mathrm{K}_{\mathrm{i}}=27.5 \mathrm{nM}\right)$ was almost threefold better than that of the Abu analog as a result of lengthening the side chain by one methylene unit. The binding affinity for the $\mu$ receptor, relative to compound $\mathbf{3}$, improved slightly as well. In compound 5, substitution with norleucine (Nle) resulted in a threefold enhancement in both $\mu$ - and $\delta$-binding affinity relative to compound 4. Interestingly, compound $5\left(\mathrm{~K}_{\mathrm{i}}=10.2\right.$ $\mathrm{nM}$ ) displayed affinity for the $\delta$ receptor site

TABLE 2

PHYSICOCHEMICAL DATA FOR DELTORPHIN I ANALOGS

\begin{tabular}{|c|c|c|c|c|c|}
\hline \multirow[t]{2}{*}{ Peptide } & \multirow[t]{2}{*}{ Compound no. } & \multicolumn{2}{|c|}{ HPLC } & \multirow{2}{*}{$\begin{array}{l}\text { Purity } \\
(\%)^{\mathrm{c}}\end{array}$} & \multirow{2}{*}{$\begin{array}{l}\mathrm{MS} \\
\mathrm{mol} \mathrm{wt}^{\mathrm{d}}\end{array}$} \\
\hline & & $\mathbf{I}^{a}$ & $11^{\mathrm{b}}$ & & \\
\hline Y-a-(Tle)-D-V-V-G-NH & $\mathbf{1}$ & 1.94 & 43.1 & 97.2 & 734.0 \\
\hline $\mathrm{Y}-\mathrm{a}-(t-\mathrm{BuAla})-\mathrm{D}-\mathrm{V}-\mathrm{V}-\mathrm{G}-\mathrm{NH}_{2}$ & 2 & 5.83 & 47.2 & 98.5 & 749.0 \\
\hline $\mathrm{Y}-\mathrm{a}-(\mathrm{Abu})-\mathrm{D}-\mathrm{V}-\mathrm{V}-\mathrm{G}-\mathrm{NH}_{2}$ & 3 & 0.45 & 38.8 & 96.0 & 706.5 \\
\hline Y-a-(Nva)-D-V-V-G-NH & 4 & 1.25 & 42.7 & 98.4 & 720.5 \\
\hline $\mathrm{Y}-\mathrm{a}-(\mathrm{Nle})-\mathrm{D}-\mathrm{V}-\mathrm{V}-\mathrm{G}-\mathrm{NH}_{2}$ & 5 & 2.59 & 46.9 & 99.8 & 735.0 \\
\hline $\mathrm{Y}-\mathrm{a}-(\mathrm{Cpa})-\mathrm{D}-\mathrm{V}-\mathrm{V}-\mathrm{G}-\mathrm{NH}_{2}$ & 6 & 2.52 & 43.4 & 95.0 & 760.5 \\
\hline $\mathrm{Y}$-a-(Oic)-D-V-V-G-NH ${ }_{2}$ & 7 & 4.26 & 45.2 & 95.0 & 772.5 \\
\hline
\end{tabular}

a HPLC $\mathrm{K}^{\prime}$ on a Vydac $218 \mathrm{TP} \mathrm{C}_{18}$ column $(0.46 \mathrm{~cm} \times 25 \mathrm{~cm})$; isocratic conditions at $25 \%$ organic component; flow rate of 1 $\mathrm{ml} / \mathrm{min}$. The solvent system was $0.1 \%$ TFA in water, $0.1 \%$ TFA in acetonitrile. Solvent front breakthrough at $3.4 \mathrm{~min}$.

${ }^{b}$ HPLC retention time in min on a Vydac $218 \mathrm{TP} \mathrm{C}_{18}$ column $(0.46 \mathrm{~cm} \times 25 \mathrm{~cm})$; gradient of $0-50 \%$ organic component in $50 \mathrm{~min}$; flow rate of $1 \mathrm{ml} / \mathrm{min}$. The solvent system was $0.1 \%$ TFA in water, $0.1 \%$ TFA in acetonitrile. Solvent front breakthrough at 3.5 $\min$.

c Purity of final product peptide as assessed by RP-HPLC peak integration at 214 or $230 \mathrm{~nm}$ (whichever is lower).

d Molecular weight obtained by electrospray mass spectrometry. 
within an order of magnitude of the native parent peptide, even though the side chain of residue three consisted of an $n$-butyl group rather than an aromatic benzyl moiety. Both compounds 4 and 5 were approximately 100 -fold selective for the $\delta$ receptor over the $\mu$ receptor.

$\beta$-Cyclopentylalanine ( $\mathrm{Cpa}$ ) was substituted for $\mathrm{Phe}^{3}$ due to its lipophilic and nonaromatic, but relatively planar, nature. The $\delta$ affinity of compound $6\left(\mathrm{~K}_{\mathrm{i}}=366 \mathrm{nM}\right)$ was much weaker than that of deltorphin I. Although $\mu$ binding also was quite poor, this analog suffered a great loss in $\delta$ selectivity, with a $\mu$ to $\delta \mathrm{K}_{\mathrm{i}}$ ratio of only 12 . Ana$\log 7$, containing octahydroindole-2-carboxylic acid (Oic), displayed similarly low affinity for the $\delta$ opioid receptor $\left(\mathrm{K}_{\mathrm{i}}=423 \mathrm{nM}\right)$, despite its lipophilicity. Binding to the $\mu$ receptor was negligible as well.

\section{DISCUSSION}

The poor $\delta$-binding affinity of analog 1 confirms our earlier suggestion that $\beta$-substitution on the side chain of residue three adversely influences $\delta$ receptor interaction [11]. The side chain of Tle is lipophilic, has the same number of carbons as that of leucine, and is the same length as that of valine, but it is further substituted at the $\beta$-carbon. This must be an unfavorable condition, since the $\delta$-binding affinity suffers 200 -fold relative to that of the leucine analog $\left(\mathrm{K}_{\mathrm{i}}=12.4 \mathrm{nM}\right)$ and 16fold relative to that of the valine analog $\left(\mathrm{K}_{\mathrm{i}}=160\right.$ $\mathrm{nM})$. It should be noted that a progressive decrease in $\delta$ affinity was observed for analogs containing Leu $\left(\mathrm{K}_{\mathrm{i}}=12.4 \mathrm{nM}\right)$ [11], Ile $\left(\mathrm{K}_{\mathrm{i}}=94.7\right.$ $\mathrm{nM})$ [11], and Tle $\left(\mathrm{K}_{\mathrm{i}}=2590 \mathrm{nM}\right)$, which have respectively one, two and three additional alkyl substituents at their $\beta$-carbons. The data presented here suggest that the steric and/or conformational effect triggered by substitution at the $\beta$ carbon is the primary factor in determining relative binding affinity for the $\delta$ receptor within this group of analogs.

In contrast, the $t$-BuAla analog, 2, lacks steric hindrance around its $\beta$-carbon, which might per- mit the molecule to fold into a more favorable binding conformation for interaction at the $\delta$ receptor site. The side chain length of $t$-BuAla parallels that of leucine, so it is somewhat surprising that the $\delta$ affinity of compound $\mathbf{2}$ is slightly less than that of the previously reported $\mathrm{Leu}^{3}$ analog [11]. Still, it should be noted that the affinities are within an order of magnitude. It is also possible that the $\gamma t$-butyl group is too large to fit the binding site optimally or contributes to an adverse steric effect on conformation.

One factor that is influenced by the degree of $\beta$-substitution is planarity of the side chain. It appears that the $\delta$ binding pocket may be narrow and selective with regard to where steric bulk is tolerated, easily allowing binding of the flat phenylalanine aromatic ring. Each subsequent addition of a $\beta$-substituent in our analogs progressively interferes with the ability of the side chain to adopt a 'flat' conformation, with the third substituent (as in a $t$-butyl group) absolutely forcing the groups out of plane. This effect may be due to the influence on overall peptide topology as well as obstructing a 'fit' of the side chain into the binding pocket. The effect of a $t$-butyl group on peptide binding appears more drastic when it is substituted closer to the backbone (analog 1); substitution at the $\gamma$ carbon in analog 2 is not nearly as detrimental. While both analogs contain similarly bulky side chains, the latter analog might be expected to have greater local conformational flexibility at the third residue. Indeed, it has been noted that rotational freedom of this side chain is an important element in the $\delta$ binding interaction. Restriction of the phenylalanine side chain via formation of a double bond between the $\alpha$ and $\beta$ carbons decreased $\delta$ binding 14-fold, while enhancing $\mu$ affinity [15]. In addition, nuclear Overhauser spectroscopy studies have revealed a proximity between the methyl group of D-Ala ${ }^{2}$ and the side chain of residue three [21,22], and it has been suggested that a steric interaction between these groups might change the conformation of the $\beta$-turn at the $N$-terminus of the peptide [15]. Furthermore, molecular modeling stud- 
ies of deltorphin analogs have shown potential intramolecular interactions between $\mathrm{Phe}^{3}$ and both the $\mathrm{Tyr}^{1}$ phenolic ring and the $\mathrm{Asp}^{4}$ side chain [15]. The steric distribution of the side chain of residue three therefore may be an important determinant in maintaining the appropriate binding conformation.

The binding profiles of analogs 3-5 also tend to support the assumption that substitution at the $\beta$-carbon disrupts the proper orientation of the molecule for binding to $\delta$ receptors. In these compounds, the importance of side chain length was explored. Apparently, a long unsubstituted alkyl chain at position three can function as an integral component in the binding interaction, most likely through hydrophobic forces. In addition, the optimal spatial orientation of other pharmacophoric elements required for binding to the $\delta$ receptor site is preserved. While compound 3 does not bind particularly well, its side chain is rather short and the least lipophilic of the group. As the length of the alkyl chain is extended in 4 and 5 , binding to the $\delta$ receptor improves significantly, with the affinity of analog 5 being comparable to that of deltorphin I itself. This most likely occurs because the side chain of norleucine is long enough to reach the binding site of the $\delta$ receptor and should be able to interact through hydrophobic interactions with the $\delta$ receptor site in a similar manner to that of the phenylalanine side chain. In addition, the $\beta$-carbon is unsubstituted, resulting in the highest $\delta$ affinity of all analogs reported here. The $\delta$ opioid affinity of analog 5 also is commensurate with that of [Leu ${ }^{3}$ deltorphin I $\left(\mathrm{K}_{\mathrm{i}}=12.4 \mathrm{nM}\right)$ [11]; this is logical given the similar structural characteristics of Leu and Nle.

There is a remarkable contrast (40-fold difference) between the $\delta$-binding affinities of analogs containing $\beta$-cyclohexylalanine $\left(\mathrm{K}_{\mathrm{i}}=10.5 \mathrm{nM}\right)$ [11] and $\beta$-cyclopentylalanine (analog 6) at position three. Apparently, the van der Waals space occupied by a flexible cyclohexyl group in the chair conformation more closely approximates that of the phenylalanine phenyl ring than does that of a cyclopentyl group, regardless of the relative planarity of the latter. While bulky and lipophilic, the side chain of $\beta$-cyclopentylalanine is relatively rigid, as the carbons in the five-membered ring possess little flexibility. This may prevent the appropriate arrangement of atoms for interaction at the receptor binding pocket. However, it is interesting to note that the aromatic five-membered ring of $\beta$-thienylalanine is well accommodated at this position [16].

Oic is structurally similar to $\beta$-cyclohexylalanine, but is more constrained. The decrease in conformational mobility of the side chain of ana$\log 7$ apparently prevents ideal interaction with the $\delta$ receptor site, since its affinity is $1 / 40$ that of [Cha ${ }^{3}$ ]deltorphin I [11]. Also, this substitution may adversely influence local backbone angles by virtue of cyclization via the $\alpha$-nitrogen. Substitution of bicyclic aromatic systems for the benzyl moiety of phenylalanine has been shown to be well tolerated in general [15]. However, replacement of $\mathrm{Phe}^{3}$ by 1,2,3,4-tetrahydroisoquinoline-3carboxylic acid (Tic) resulted in a substantial loss in $\delta$ affinity [15], confirming similar effects on other opioid peptides [7,23]. This was at least partially attributed to the cyclization via the amide nitrogen, since $\mathrm{N}$-methylphenylalanine also is a deleterious substitution in position three [15]. Oic shares this unfavorable structural feature, which probably contributes to its poor binding profile.

\section{CONCLUSIONS}

Although none of the analogs examined in this study bound as well or were as $\delta$-selective as the parent deltorphin I, our results provide further evidence that aromaticity at position three, while preferred, clearly is not a requirement for interaction with the $\delta$ receptor. In addition, the side chain must be lipophilic, sufficiently long/flexible to reach the binding pocket (possibly interacting with the receptor by van der Waals interactions or hydrophobic forces), and have minimal $\beta$-substitution. The high $\delta$-binding affinity and selectiv- 
ity of compound 5 (containing $\mathrm{Nle}$ ) is remarkable for an opioid peptide that lacks an aromatic side chain at the third residue.

\section{ACKNOWLEDGEMENTS}

Opioid receptor binding assays were graciously performed under the direction of Dr. Henry I. Mosberg at the University of Michigan. Electrospray mass spectral analyses were provided by Dr. Phil Andrews and colleagues at The University of Michigan Protein and Carbohydrate Structure Facility. Funding for this research has been provided by the Eastern Michigan University chemistry department, a Provost's Research Award for New Faculty at EMU, the EMU Graduate School Support Fund, and primarily by a Bristol Myers-Squibb Award of Research Corporation.

\section{REFERENCES}

1 Erspamer, V., Int. J. Dev. Neurosci., 10 (1992) 3.

2 Salvadori, S., Marastoni, M. and Balboni, G., J. Med. Chem., 34 (1991) 1656.

3 Lazarus, L.H., Salvadori, S., Attila, M., Grieco, P., Bundy, D.M., Wilson, W.E. and Tomatis, R., Peptides, 14 (1993) 21.

4 Sagan, S., Charpentier, S., Delfour, A., Amiche, M. and Nicolas, P., Biochem. Biophys. Res. Commun., 187 (1992) 1203.

5 Mosberg, H.I., Kroona, H.B., Omnaas, J.R., ScobczykKojiro, K., Bush, P. and Mousigian, C., In Hodges, R.S. and Smith, J.A. (Eds.) Peptides: Chemistry, Structure and Biology (Proceedings of the 13th American Peptide Symposium), ESCOM, Leiden, 1994, pp. 514-516.

6 Misicka, A., Lipkowski, A.W., Horvath, R., Davis, P. and Kramer, T.H., Life Sci., 51 (1992) 1025.

7 Schiller, P.W., Weltrowska, G., Nguyen, T.M.-D., Wilkes,
B.C., Chung, N.N. and Lemieux, C., J. Med. Chem., 35 (1992) 3956.

8 Geza, T., Russell, K.C., Landis, G., Kramer, T.H., Fanh, L., Knapp, R., Davis, P. and Burks, T.F., J. Med. Chem., 35 (1992) 2384.

9 Hruby, V.J. and Gehrig, C.A., Med. Res. Rev., 9 (1989) 343.

10 Salvadori, S., Bianchi, C., Lazarus, L.H., Scaranari, V., Attila, M. and Thomas, R., J. Med. Chem., 35 (1992) 4651.

11 Heyl, D.L., Schmitter, S.J., Bouzit, H., Johnson, T.W., Hepp, A.M., Kurtz, K.R. and Mousigian, C., Int. J. Pept. Protein Res., 44 (1994) 420.

12 Heyl, D.L. and Mosberg, H.I., Int. J. Pept. Protein Res., 39 (1992) 450.

13 Mosberg, H.I., Heyl, D.L., Omnaas, J.R., Haaseth, R.C., Medzihradsky, F. and Smith, C.B., Mol. Pharmacol., 38 (1990) 924.

14 Heyl, D.L. and Mosberg, H.I., J. Med. Chem., 35 (1992) 1535.

15 Salvadori, S., Bryant, S., Bianchi, C., Balboni, G., Scaranari, V., Attila, M. and Lazarus, L., J. Med. Chem., 36 (1993) 3748.

16 Heyl, D.L., Dandabathula, M., Kurtz, K.R. and Mousigian, C., J. Med. Chem., 38 (1995) 1242.

17 Dutta, A.S., Gormly, J.J., Hayward, C.F., Morley, J.S., Shaw, J.S., Stacey, G.J. and Turnbull, M.T., Acta Pharm. Suec. (Suppl.), 14 (1977) 14.

18 Kaiser, E., Colescott, R.L., Bossinger, D.C. and Cook, P.I., Anal. Biochem., 34 (1970) 595.

19 Munson, P.J. and Rodbard, D., Anal. Biochem., 107 (1980) 220.

20 Wilce, M.C.J., Aguilar, M.-L. and Hearn, M.T.W., Anal. Chem., 67 (1995) 1210.

21 Amodeo, P., Motta, A., Tancredi, T, Salvadori, S., Tomatis, R., Picone, D., Saviano, G. and Tesmussi, P., Pept. Res., 5 (1992) 48.

22 Tancredi, T., Tasmussi, P., Picone, D., Amodeo, P., Tomatis, R., Salvadori, S., Marastoni, M., Santagada, V. and Balboni, G., Biopolymers, 31 (1991) 751.

23 Schiller, P.W., Weltrowska, G., Nguyen, T.M.-D., Lemieux, C., Chung, N.N., Marsden, B.J. and Wilkes, B.C., J. Med. Chem., 34 (1991) 3128. 